\title{
特集 若手研究者
}

\section{性転換魚ホシササノハベラからみる 可塑的な性のメカニズム}

太田 耕 平 (基礎生物学研究所・生殖生物学研究部門・

日本学術振興会特別研究員)

生物の中には自然状態で性を換えるものが 少なからず存在しています1)。例えば無脊椎 動物では貝類や甲殼類等がよく知られており、 植物の中にも性転換するものがみられます。 脊椎動物の中では両生類と魚類にみられ、特 に魚類では数百もの種が性転換すると言われ ています。これらの中には雌から雄へ換わる もの、雄から雌へ換わるもの、両方向へ一生 の間に何度でも換わることができるものが含 まれており、性転換のきっかけも年齢・成長 や社会環境など、種によって様々です。また、 系統分類上も多岐にわたります。これまで魚 類の性転換に関しては行動生態学や進化生態 学の立場から盛んに研究が行われ、様々な性 転換魚の繁殖行動や社会構造が明らかにされ るとともに、性を転換することの適応的意義 が議論されてきました ${ }^{2)}$ 。その一方で、性転 換の仕組み、すなわち生理メカニズムについ ては最近、細胞生物学や分子生物学的手法を 用いた研究が進展してきましたが、未だ不明 な点は多く、研究対象とされている魚種も限 られています。そこで私たちはホシササノ八 ベラという魚をモデル動物として選び、性転 換のメカニズムについて研究を行ってきまし た。本稿ではこれまでに得られた情報を簡単 にご紹介させて頂きます。

\section{ホシササノハベラについて}

性転換の仕組みを調べるためのモデル動物 の条件として、当初に私たちが重視していた のは、「個体を大量に確保できること」と「水 槽内で自在に性転換を誘導できること」の2 点です。しかし、これらの条件を満たす魚は

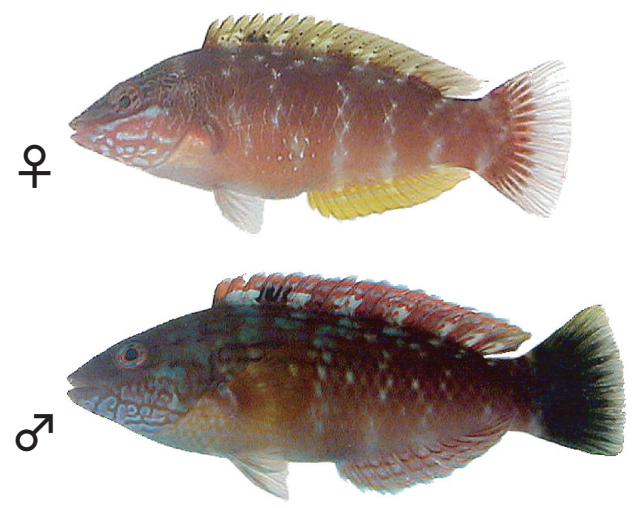

図1ホシササノハベラPseudolabrus sieboldi 性転換に伴い体色変化する。尻ビレに最も大 きな色相変化がみられ、これを指標に性転換の 進行度を判別できる。

意外に稀であり、熱帯域に生息するハワイ産 のベラ科魚 (Thalassoma duperrey) などごく一 部の種に限られていました。そこで、国内に おいて「個体を大量に確保できる」という条 件を満たす、ホシササノハベラ (Pseudolabrus sieboldi) (図1) に着目し、水槽内での性転換 の誘導を試みました。ホシササノハベラは西 日本沿岸の岩礁域に棲む魚で、スズキ目べラ 科ササノハベラ属に分類されます。ハワイ産 ベラと同じベラ科に属しますが、ササノハベ ラ属の魚は全て北太平洋または南太平洋の温 带域のみに生息する、いわば温帯域に特化し たベラの仲間です。ホシササノ八ベラは通常、 最初に雌として成熟し、その後、ある社会環 境におかれた時に雄へ性転換します。この 際に、卵巣は精巣へ完全に置き換わり（図2)、 体色も大きく変化します。なかでも特に尻ビ レの色相が黄から赤へ大きく変わることから、 

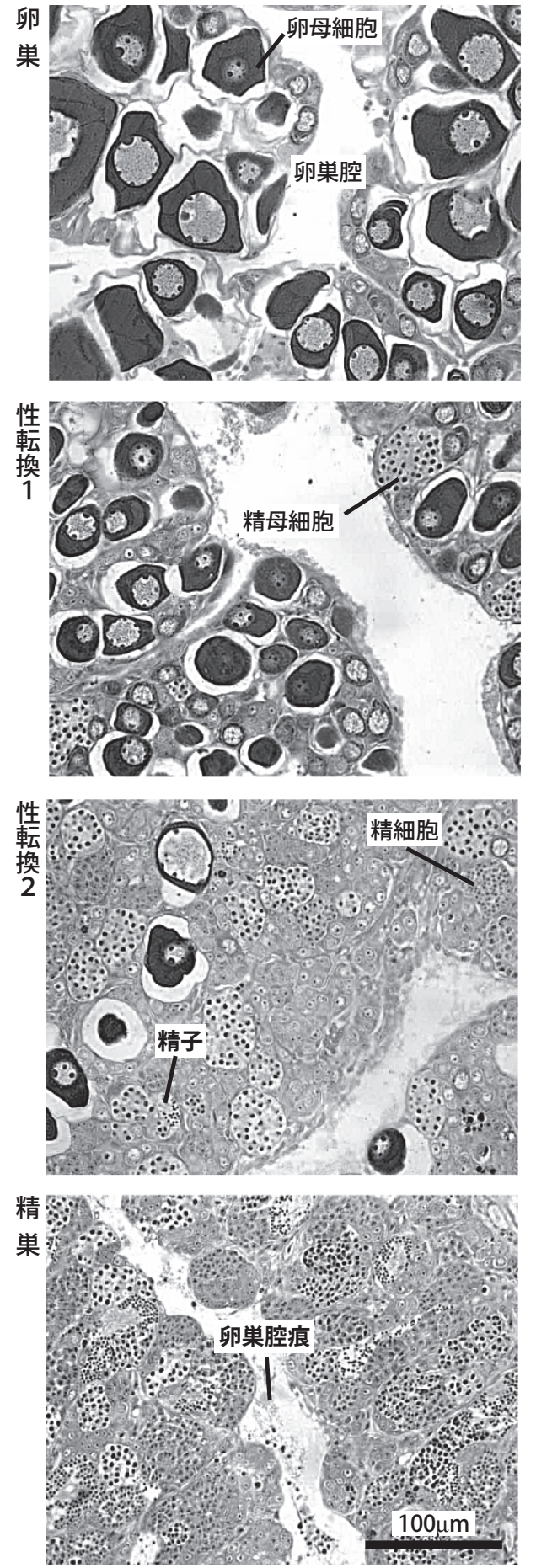

図2 性転換に伴う生殖腺組織の変化

卵单組織内から雄性生殖細胞が出現し、最終 的には精巣組織へ完全に置き換わる。性転換後 も卵巣腔は痕跡として残る。
これを元に雌雄および性転換個体の判別を容 易に行うことができます。

\section{水槽内における性転換の誘導 (雌から雄)}

八ワイ産べラでは体長の異なる2尾の雌を 水槽に入れた場合、大きな方が雄に換わる、 ということがよく知られています 3 。 。私たち はホシササノハベラを用いて、同様に雌 2 尾 の飼育実験を行いましたが、全く性転換は起 こりませんでした。そこで、雌の数を増やし たところ、雌3尾の実験区で低頻度ながら雄 へ性転換する個体がみられました。さらに雌 6尾を同居させると必ずその中の 1 尾が雄へ 性転換しました (図3)。この際に性転換を起 こすのは、水槽内で相対的に最も大きな個体 または2番目の個体のどちらか一方です。特 に1番目と2番目の個体との体長差が小さい 場合には、2番目の個体の性転換がしばしば 起こりました。そこで、水槽の中で最も大き な個体を他の個体と $1 \mathrm{~cm}$ 以上の体長差をつけ て同居させると、確実に最大の個体が性転換 しました。また、最大個体を水の入れ替えの ない透明板を用いて他の個体と隔てた場合で も、性転換が起こることから、ホシササノハ ベラは体長差と尾数を主に視覚情報により認 識し、グループ内で優位に立つた時に雄へ性 転換すると考えられました。また、体長差が 少ない場合には攻撃行動が盛んに観察される ことから、この場合には視覚以外の情報も利 用している可能性が考えられます。

\section{雄から雌の逆方向転換}

一般に、性転換の方向性はその種における 繁殖システムと密接に関連しているといわれ ています。この十数年の間に双方向へ性転換 する魚の報告が相次ぎましたが、それらはダ ルマハゼ (Paragobiodon echinocephalus) やオキ ナワベニハゼ (Trimma okinawae)、ホンソメ ワケベラ(Labroides dimidiatus) などの一夫一 妻もしくは一夫多妻の配偶システムを持つ ものに限られていましだ)。一方、ホシササ ノハベラは自然環境下において、雄がなわば 

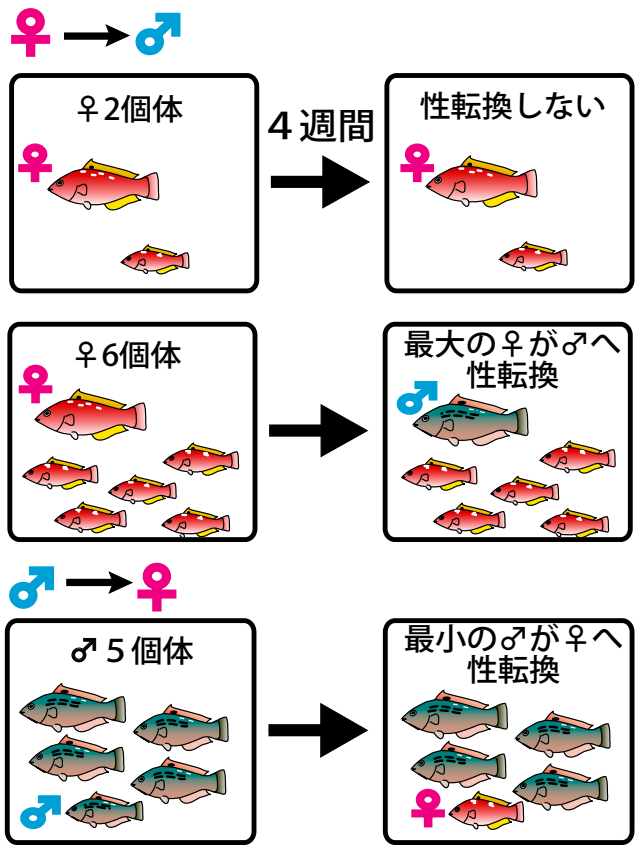

図3性転換誘導のための飼育条件

雌 2 尾の同居では性転換は起こらないが、雌 6 尾の同居により最大の 1 尾が確実に雄へ性転換す る。また、雄 5 尾の同居により、最小の 1 尾が雌 へ逆方向の性転換をする。

りをつくり、なわばり内に入ってくる自分よ り小さな雌と産卵を行います。また、雌は雄 のなわばりにとどまることなく自由に複数の 雄のなわばりに出入りして産卵することがで きる、いわゆる雌雄共に複婚 (両性複婚) の 繁殖システムを持ちます。このような魚種で は、双方向転換の報告はなく、一度性転換し た雄は雌へは戻らないものと考えられていま した。しかしながら、雄5尾を水槽に収容し たところ、最小個体の体色が雌型へ換わると ともに、生殖腺も卵巣を有していました。す なわち、ホシササノハベラは通常、雌から雄 へ性転換しますが、雄から雌の逆方向へも性 転換する能力をもつことが初めて明らかとな りました。このような双方向性転換の機能が 全ての性転換魚に保持されているのか、それ ともやはり何らかの繁殖システムと関連して いるかは興味深い問題です。

\section{性ステロイドホルモンによる生殖腺の転換}

性転換は機能的側面から、卵形成と精子形 成の間の転換と捉えることができます。性転 換魚においても雌雄の配偶子形成は、他の脊 椎動物と同様に視床下部一下垂体一生殖腺か らなる生殖内分泌系によってコントロールさ れていると考えられます。そこでまず、生殖 腺でつくられる性ステロイドホルモンについ て解析しました。雌雄の生殖腺でつくられる 性ステロイドの合成経路を同定した結果、ア ンドロゲンとエストロゲンの合成経路に雌 雄差がみられ、卵巣ではエストラジオール -17ß、精巣では11-ケトテストステロンが主 な最終産物として合成されていました。加え て、ホシササノハベラのエストロゲン合成経 路がサケ科魚やメダカ、ブリなどの雌雄異 体の魚とは異なることが明らかとなりました。 すなわち、サケ科魚やメダカではエストラジ オール-17ßはテストステロンを経由して合 成されるのに対して、ホシササノハベラでは テストステロンを経由せず、エストロンを 経て合成されていました(図4) 5)。一方、精 巣においてテストステロンは11-ケトテスト ステロンの中間代謝物として合成されます6)。 そこで次に、雌雄における性ステロイドの 血中動態を調べた結果、雄では11-ケトテス トステロンが雌よりも常に7倍程度高く、逆 に雌ではエストロンが雄よりも6倍高いこと が明らかとなりました。また、エストラジオ ール-17ßには雌雄の分泌パターンに大きな 違いがみられ、雌では常に一定範囲の高い值 を維持しているのに対し、雄ではごく短時間 の一過性の分泌パターンを示しました6)。ウ ナギなどでは精原細胞の増殖にエストラジオ ール-17ßが関与していることが示唆されて おり7)、実際にホシササノ八ベラにおいても 精原細胞数が増加する時期に血中量が高くな る傾向がみられることから、精原細胞の増殖 に関与しているものと推察されます。

以上の結果を元に、雌成魚に対してアン ドロゲン (11-ケトテストステロン、テスト ステロン)を徐放的に投与しました。その結 


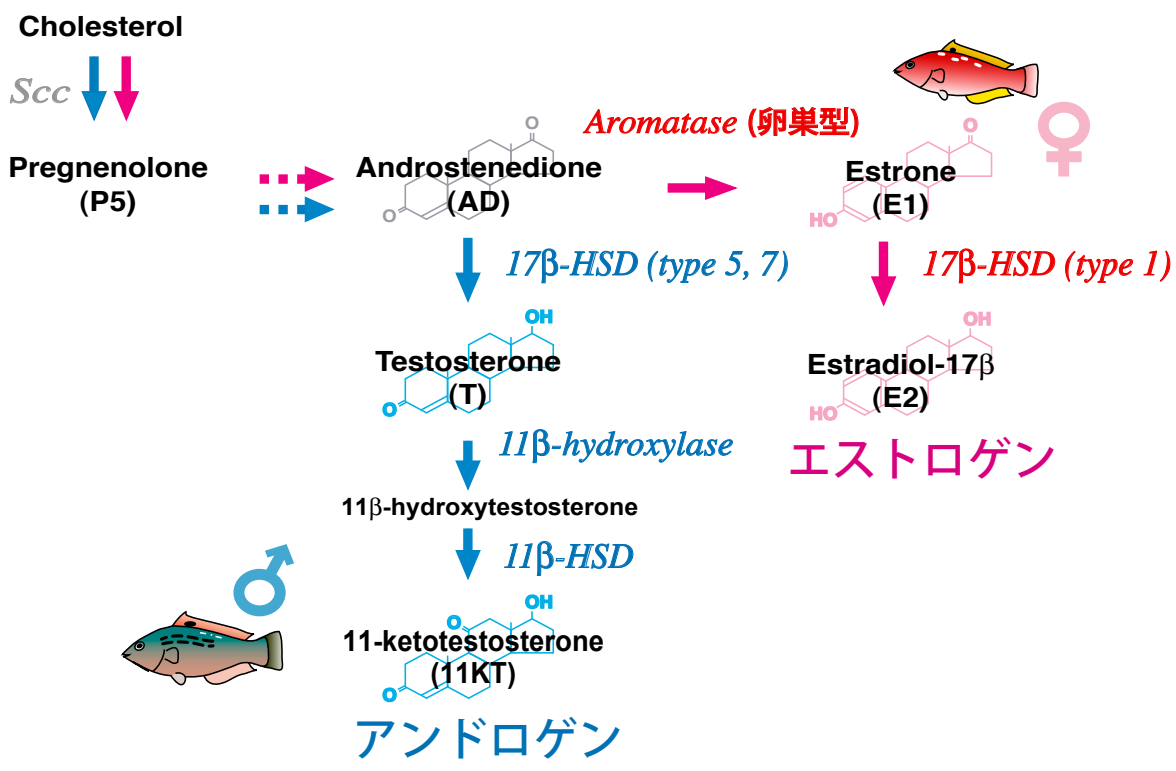

図4 生殖腺におけるエストロゲンとアンドロゲンの合成経路

性転換に伴いエストロゲン合成系とアンドロゲン合成系との間でステロイド合成系の著しい 転換が起こる。ホシササノ八ベラの卵巣において、エストラジオール-17ßはテストステロン からではなく、エストロンを経由して合成されている。

果、投与開始から4週間で体色は完全に雄型 へと換わり、生殖腺も精巣へ転換していまし た。加えて、血中エストロゲン量の低下が認 められました。逆に、雄成魚に対してエス トロゲン (エストラジオール -17 ン)を投与した結果、全ての個体において生 殖腺が卵母細胞を有する卵巣へ換わり、血中 アンドロゲン量の著しい低下が認められまし た。以上のことから、ホシササノハベラの生 殖腺では性転換に伴いアンドロステンジオン を分岐点としてエストロン $\rightarrow$ エトラジオ ール-17及のエストロゲン合成系と、テスト ステロン $\rightarrow 11$-ケトテストステロンのアンド ロゲン合成系との間でのステロイド合成系 の転換が起こることが強く示唆されました $\left.{ }^{8}\right)$ (図4)。さらに、各種ステロイド代謝酵素遺 伝子の発現解析を行った結果、エストロゲン 合成に関わる卵巣型aromatase と 17ß-HSD 1 型 (HSD17B1)、およびアンドロゲンの合成 に関わる11ß-hydroxylaseの発現量が、性転 換に伴って著しく減少または増加することか ら、これらの酵素が鍵酵素としてステロイド
合成系の転換を制御していると考えられまし た。

ところで、テストステロンの投与により雌 から雄への性転換が誘導されることから、「エ ストロン経路」は雌の卵形成時にエストラジ オール-17ßの中間代謝物としてのテストス テロンが合成されるのを避けることにより、 雌の状態を安定的に維持する役割があるので はないかと考えられます。この「エストロン 経路」はホシササノ八ベラのみならず、同じ ベラ科の性転換魚であるキュウセンや、痕跡 的雌雄同体魚 (未成熟の期間中に性転換が起 こる)であるスズキ目タイ科のマダイの雌に もみられることが最近明らかにされており9)、 少なくとも一部の性転換魚ではホシササノ八 ベラと同様のシステムを採用しているのでは ないかと考えられます。

アンドロゲンとエストロゲンが生殖腺の性 転換と密接に関与していることは古くから指 摘されており10)、それに関わる酵素の1つで ある aromataseについては詳細な研究が進ん でいますが(JSCE Newsletter No.118、小林 
靖尚さんの項参照)、生殖腺におけるステロ イド合成経路が完全に明らかにされている性 転換魚は、現在のところホシササノハベラの 他にありません。ホシササノ八ベラのステロ イド合成経路が全ての性転換魚に当てはまる かどうかは未だ不明ですが、今回、ステロイ ド合成系の転換様式とそれに関わる鍵酵素が 明らかにされたことにより、性転換に関わる 性ステロイドの機能の共通性や多様性の理解 がより一層進展するのではないかと考えられ ます。

\section{In vitroでの性転換}

また最近、私たちは雌から雄の性転換を in vitroで再現することに成功しています(琉球 大学 中村將先生との共同研究)。生殖腺の 器官培養系を確立し、ホシササノハベラ雌成 魚から採取した周辺仁期や卵黄形成初期の卵 母細胞がみられる完全な卵巣組織を、エスト ロゲンと共に4週間培養したところ、卵母細 胞が維持されたのに対し、アンドロゲンと共 に培養すると、卵母細胞が退行し、精子形成 がみられました (図5)。この結果は性ステロ イドが生殖腺の性を直接的に維持／転換して いることを強く支持しており、さらに生殖腺 内の細胞のみで卵巣から精子を形成できるこ とを示しています。一方、精巣をアンドロゲ ンと共に培養すると精巣構造が維持されるの に対し、エストロゲンと共に培養すると著し く退行してシスト構造がなくなり、減数分裂 前の未発達な生殖細胞が認められました。こ の生殖細胞が未分化な生殖細胞または精原細
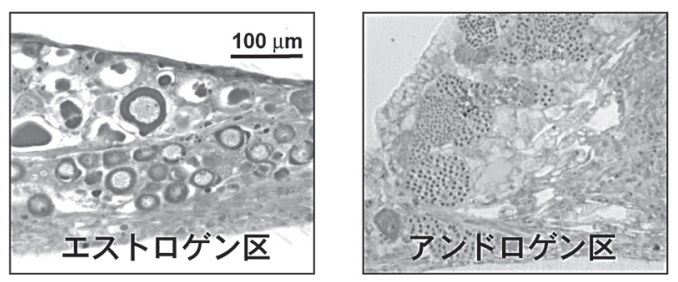

図5卵巣の器官培養

エストロゲン添加区では卵母細胞が維持され るのに対し、アンドロゲン添加区では卵母細胞 は消失し、精子形成が起こる。
胞か、それとも性転換して卵原細胞に分化し た細胞かという点について、今後さらに詳し く調べていく必要があります。

\section{生殖腺刺激ホルモン (GtH) 分泌の雌雄差}

生殖腺におけるステロイド合成系の転換を 上位で制御しているメカニズムについては、 現在のところよくわかっていません。ところ で、雌雄異体魚を含め ${ }^{11)}$ 、多くの脊椎動物 において GtHの分泌に雌雄差があることは よく知られていますが、最近、私たちはホシ ササノハベラに拈いて、GtHの分泌パ夕 ーンが雌雄で全く異なることを明らかにし ています (図6)。下垂体における、 $\alpha 、 F S H \beta$ 、 LH H のいずれのサブユニット遺伝子も雌雄 および性転換の期間、常に発現が認められま す。また同様に、生殖腺の FSH受容体およ びLH受容体の遺伝子発現も常にみられ、大 きな量的変動もみられません。しかしなが ら、各 $\mathrm{GtH}$ サブュニット遺伝子の発現動態 を詳細に調べた結果、日周の発現パターンに 明瞭な雌雄差がみられました。GtHが生殖 腺の転換に関与している可能性があること は、これまでにカリブ海産のベラ (Thalassoma bifasciatum) ${ }^{12,13)}$ などで示唆されていました

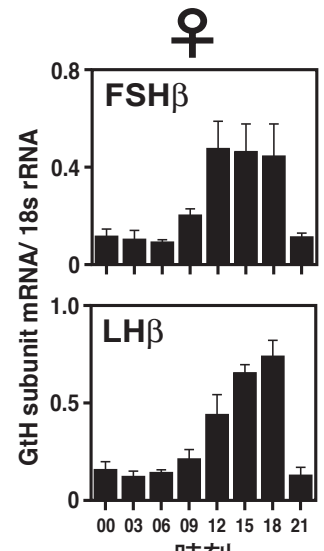

時刻

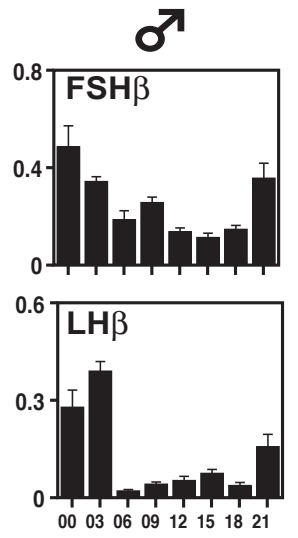

時刻
図6 下垂体におけるGtHのFSH $\beta$ 鎖およびLH $\beta$ 鎖遺伝子の発現

ノーザン解析の結果、雌雄で全く異なる日周 変動がみられた。図には示していないが、 $\alpha$ 鎖 も同様の雌雄差がみられる。 
が、その詳細は未解決なままでした。「GtH 分泌パターンの違い」は、それを解決する糸 口になるかもしれません。

\section{性転換魚の特徵}

このようにホシササノハベラにおいて $\mathrm{GtH}$ や性ステロイドの分泌に雌雄差がみら れるという結果は、性転換に伴い視床下部一 下垂体一生殖腺の生殖内分泌系が雌のパタ ーンと雄のパターンの間で切り換わるという ことを示しています (図7)。通常、雌雄異体 魚の雌雄間では自然条件下でこのような切り 換えが起こらないと推察すると、少なくとも ホシササノ八ベラでは、この生殖内分泌パ夕 ーンの切り換えが1つの特徵であり、今後ど のようなメカニズムで視覚情報が生殖内分泌 系を切り換えるかという問題が、性転換のメ カニズムを知る上での 1 つの重要な課題であ ると考えられます。一方で、単に生殖内分泌 パターンが換わっても、生殖腺器官がそれに 対応して転換しなければ、もう一方の配偶子 を新たに作り出すことができません。すなわ ち、内分泌情報の受け取り先である生殖腺器 官、さらに言えば、それを構成している生殖 細胞および生殖腺体細胞の側にも性を換える

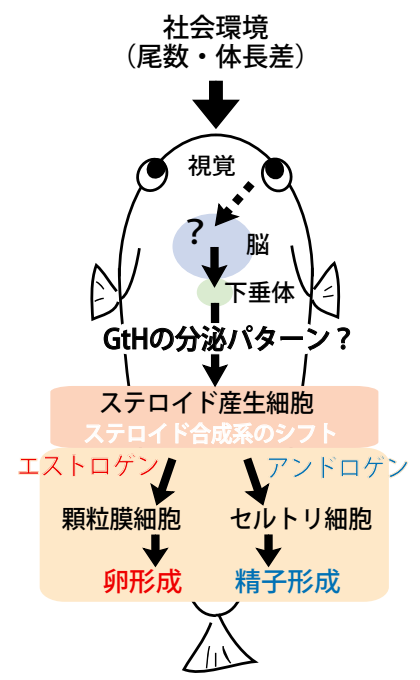

図7予想されるホシササノハベラの性転換メカ ニズム
仕組みが存在すると考えられます。実際に卵 巣から精巣へ転換する際には、発達の進んだ 減数分裂以降の卵母細胞は細胞死するのに対 し、減数分裂前の卵原細胞 (あるいは生殖原 細胞) は残ることから、これが卵や精子の元 となる幹細胞として機能していることが示唆 されます。また、生殖腺体細胞についても同 様に、細胞死するものとそうでないものがみ られます。したがって、性転換に伴ってもう 一方の性の生殖腺を形成する際に、生殖腺を 構成する各種細胞が増殖、分化、脱分化、分 化転換、あるいは細胞死し、それらが協調し て、生殖腺のダイナミックな転換をもたらし ていると考えられます。

以上のようにホシササノハベラの情報を中 心にこれまでの研究内容を述べてきました。 しかし性転換魚の中では、雌から雄、雄から 雌、双方向といった方向性だけでなく、生殖 腺の形態もホシササノ八ベラのように卵巣と 精巣が完全に入れ換わるものもいれば、卵巣 部位と精巣部位を常に持ち、性に合わせて 一方の部位を発達させるものもいます (JSCE Newsletter No.118、小林靖尚さんの項参照)。 また、厳密には性転換ではありませんが、卵 巣と精巣を一つの体の中で同時に成熟させる という魚(同時的雌雄同体)もいます。これ らのメカニズムにどのような違いがみられる かは、性転換魚の成り立ちや、魚類における 性の多様性を知る上で大変興味深い問題です。

それでは性転換魚にみられる性的可塑性 は、他の脊椎動物にはない、特別なものなの でしょうか? 哺乳類では、人為的な遺伝子 破壊や強制発現、さらに発生初期の未分化な 生殖細胞の移植実験などにより、遺伝的性に かかわらず生殖腺や生殖細胞の性が摇らいだ り、もう一方の性の生殖腺へ換わることが知 られています14〜17)。さらに、多くの雌雄異 体の魚類では、性的未分化な時期や性分化時 期に性ステロイド処理を行うことによって、 もう一方の性へ個体を完全に換えることも可 能です。しかしながら、性分化過程を経て成 
体となった後の雌雄異体魚では、人為的なホ ルモン調節を行った場合でも、個体の性を完 全に換えることは困難です。したがって、本 稿のホシササノ八ベラや他の性転換魚 ${ }^{10)} に$ おいて認められる、性ステロイドホルモン投 与による成体の性の換わりやすさは、性転換 魚の有する性的可塑性の特徵を反映している ものと考えられます。一方、器官や細胞のレ ベルでみた場合、雌雄異体魚の成体において も、人為的ホルモン調節により性行動が転換 することが知られており ${ }^{18)}$ 、さらに生殖腺 の性が乱れたり10)、完全に生殖腺の転換が みられることもあります19)。また、ニジマ スでは雄成魚から得た精原幹細胞を雌仔魚へ 移植したところ、最終的に受精可能な卵がで きることが確認されています20）。したがって、 魚類ではひとたび性が分化した後でも、脳 や生殖腺の器官・細胞レベルでは性的可塑性 は保持されているものと考えられます。一方、 哺乳類においても最近、顆粒膜細胞がセルト リ様細胞に分化転換できることが報告されて いることから 21$)$ ある種類の細胞において は、“性転換”のメカニズムが広く保持されて いるのかもしれません。

性転換魚は、細胞一器官一個体における “性的可塑性”のメカニズムを解析するため の良い研究材料であり、その共通性や多様性 を明らかにすることにより、さらに深く脊椎 動物の性の仕組みについて理解することがで きると考えられます。

\section{謝 辞}

本研究を行うにあたり基礎生物学研究所生 殖生物学研究部門の長濱嘉孝先生、および九 州大学農学部海洋生物学研究分野の松山倫也 先生にご指導賜りました。また、琉球大学熱 帯生物圈研究センターの中村將先生、帝京科 学大学の平井俊朗先生、熊本大学理学部の北 野健先生にはご助言を頂くと共に、共同研究 をさせて頂いています。ホシササノハベラの 生態に関する情報は元九州大学農学部水産増 殖学研究分野の中園明信先生からご助言頂き
ました。また、独立行政法人水産総合セン夕 一養殖研究所の田中秀樹先生、松原創研究員 には実験魚の採集および飼育にご協力頂きま した。さらに本研究を遂行するにあたりご助 言、ご協力頂きました基礎生物学研究所生殖 生物学研究部門および九州大学農学部海洋生 物学研究分野 / 水族生産学分野のスタッフ、 研究員、学生の方々に深く感謝致します。本 研究は日本学術振興会特別研究員制度による 援助のもと、行われています。

なお、ホシササノ八ベラには、ハワイ産 ベラ科魚 (Thalassoma duperrey) などと同様に、 生まれながらに雄である一次雄が存在してい ます。こちらは性転換しないとされているた め本稿では省略致しましたが、詳細は「魚類 の性転換、中園明信、桑村哲生編、東海大学 出版会 (1987)」などに記されていますのでご 参考にして下さい。

\section{文 献}

1 ) Policansky D (1982) Sex change in plants and animals. Ann. Rev. Ecol. Syst. 13, 471-495.

2 ) Warner RR (1975) The adaptive significance of sequential hermaphroditism in animals. Amer. Nat. 109, 61-82.

3 ) Ross RM, Losey GS, Diamond M (1983) Sex change in a coral reef fish: dependence of stimulation and inhibition of relative size. Science 221, 574-575.

4 ) Kuwamura T, Nakashima Y (1998) New aspects of sex change among reef fishes: recent study in Japan. Env. Biol. Fish 52, 125-135.

5 ) Ohta K, Mine T, Yamaguchi A, Matsuyama M (2001) Steroidogenic pathway to estradiol-17 $\beta$ synthesis in the ovarian follicles of the protogynous wrasse, Pseudolabrus sieboldi. Zool. Sci. 18, 973-945.

6 ) Sundaray JK, Ohta K, Yamaguchi A, Suzuki K, Matsuyama M (2003) Diurnal rhythm of steroid biosynthesis in the tes- 
tis of terminal phase male of protogynous wrasse, Pseudolabrus sieboldi. Fish Physiol. Biochem. 28, 193-195.

7 ) Miura T, Miura C, Ohta T, Nader MR, Todo T, Yamauchi K (1999) Estradiol-17 $\beta$ stimulates the renewal of spermatogonial stem cells in males. Biochem. Biophys. Res. Commun. 264, 230-234.

8 ) Ohta K, Sundaray JK, Okida T, Sakai M, Kitano T, Yamaguchi A, Matsuyama M (2003) Bi-directional sex change and its steroidogenesis in the wrasse, Pseudolabrus sieboldi. Fish Physiol. Biochem. 28, 173-174.

9) Ohta K, Yamaguchi S, Yamaguchi A, Gen K, Okuzawa K, Kagawa H, Matsuyama M (2002) Biosynthesis of estradiol-17 $\beta$ in the ovarian follicles of the red seabream Pagrus major during vitellogenesis. Fish. Sci. 68, 680-687.

10) Devlin RH, Nagahama Y (2002) Sex determination and sex differentiation in fish: an overview of genetic, physiological, and environmental influences. Aquaculture 208, 191-364.

11) Ando H, Urano A (2005) Molecular regulation of gonadotropin secretion by gonadotropin-releasing hormone in salmonid fishes. Zool. Sci. 22, 379-389.

12) Koulish S, Kramer CR (1989) Human chorionic gonadotropin (hCG) induceds gonad reversal in a protogynous fish, the bluehead wrasse, Thalassoma bifasciatum (Teleostei, Labridae). J. Exp. Zool. 252, 156-168.

13) Kramer CR, Caddell MT, BubenheimerLivolsi L (1993) sGnRH-A ((D-Arg ${ }^{6}$, Pro ${ }^{9}$, Net-) LHRH) in combination with domperidone induces gonad reversal in a protogynous fish, the bluehead wrasse,
(Thalassoma bifasciatum). J. fish Biol. 42, 185-195.

14) Brennan J, Capel B (2004) One tissue, two fates: molecular genetic events that underlie testis versus ovary development. Nat. Rev. Genet. 5, 509-521.

15) Yao HH (2005) The pathway to femaleness: current knowledge on embryonic development of the ovary. Mol. Cell. Endocrinol. 230, 87-93.

16) Wilhelm D, Koopman P (2006) The makings of maleness: towards an integrated view of mele sexual development. Nat. Rev. Genet. 7, 620-631.

17) Adams IR, McLaren A (2002) Sexually dimorphic development of mouse primordial germ cells: switching from oogenesis to spermatogenesis. Development 129, 1155-1164.

18) Stacey N, Kobayashi M (1996) Androgen induction of male sexual behaviors in female goldfish. Horm. Behav. 30, 434-445.

19) Bhandari RK, Nakamura $M$, Nagahama Y (2006) Evidence for existence of sexual plasticity in the adult gonochoristic fish. Proceedings of the 4th International Symposium on the Biology of Vertebrate Sex Determination. P. 101-102.

20) Okutsu T, Suzuki K, Takeuchi Y, Takeuchi T, Yoshizaki G (2006) Testicular germ cells can colonize sexually undifferentiated embryonic gonad and produce functional eggs in fish. Proc. Natl. Acad. Sci. USA 103, 2725-2729.

21) Guigon CJ, Coudouel N, Mazaud-Guittot S, Forest MG, Magre S. (2005) Follicular cells acquire sertoli cell characteristics after oocyte loss. Endocrionology 146, 2992-3004. 